\title{
Determination of physico-chemical properties of two Varieties of okra traditionally dried
}

\author{
Joel Brice Kouassi ${ }^{1}$, Cisse-Camara Massara ${ }^{1}$, Georges Gnomblesson Tiahou ${ }^{1}$, \\ Absalon Ake Monde ${ }^{1}$, Daniel Essiagne Sess ${ }^{1}$, Etienne Tia vama ${ }^{2}$ \\ ${ }^{1}$ Laboratory of Biochemistry, Medical Sciences Faculty, University Felix Houphouet Boigny Abidjan, 01 BP 240 Abidjan, Ivory Coast \\ ${ }^{2}$ Laboratory Industrial Synthesis Processes of the Environment and New Energy of the National Polytechnic Institute Felix Houphouet \\ Boigny Yamoussoukro
}

\section{Email address:}

joelbricekouassi@yahoo.fr(J. B. Kouassi)

\section{To cite this article:}

Joel Brice Kouassi, Cisse-Camara Massara, Georges Gnomblesson Tiahou, Absalon Ake Monde, Daniel Essiagne Sess, Etienne Tia vama. Determination of Physico-Chemical Properties of Two Varieties of Okra Traditionally Dried. Journal of Food and Nutrition Sciences. Vol. 1, No. 4, 2013, pp. 38-42. doi: 10.11648/j.jfns.20130104.12

\begin{abstract}
The causes of food shortages in developing countries are many and frequent. This work was conducted in order to evaluate some physico-chemical properties of two varieties of dried okra consumed in Côte d'Ivoire. These varieties have been grown and harvested in Yamoussoukro. For Baoule variety, protein, fat, total sugars, reducing sugars, vitamin E, water, ash, dry matter, total carbohydrates, starch, sucrose, crude fiber and energy value are respectively $17.15 \pm 0.01,2.02 \pm$ $0.25,14.66 \pm 4.13,0.86 \pm 0.05,0.087,7.28 \pm 0.50,9.61 \pm 0.36,92.71 \pm 0.36,63.92 \pm 0.75,44.33 \pm 3.88,13.10 \pm 4.35,7.83 \pm$ $0.21,342.51 \pm 2.97$. For Dioula variety, these levels are respectively $15.75 \pm 0.2,2.17 \pm 0.11,20,0.83 \pm 0.05,0.15,7.33 \pm$ $0.20,9.50 \pm 0.10,92.60 \pm 0.30,65.24 \pm 0.25,40.71 \pm 0.23,18.20 \pm 0.05,9.07 \pm 1.96,343.14 \pm 0.97$. No significant difference was observed at the threshold of $5 \%$ for the levels of lipids, total sugars, reducing sugars, water, ash, dry matter, starch, sucrose, crude fiber and energy values of the two varieties. However, a significant difference was observed at the $5 \%$ threshold for the levels of protein, vitamin E and total carbohydrate. Furthermore, the content of anti-nutritional factors was low in samples except leucoanthocyanes and catechin tannins.
\end{abstract}

Keywords: Physicochemical, Okra, Traditionally Dried

\section{Introduction}

Okra is one of the most consumed spices in the countries of Africa and Asia [1,2,3]. World production of fruits is estimated at about four million tons with India head (3.5 million tons), or about $15 \%$ of the total vegetable production. $85 \%$ of the production comes from developing countries [4]. In West Africa, Nigeria is the largest producer $(1,039.000 \mathrm{t})$ followed by the Ivory Coast and Ghana. In Ivory Coast, two species are cultivated $[5,6,7,8]$ : Abelmoschus esculentus and Abelmoschus caillei under the name of gombo in french, okra in English, quiabero in Spanish and many common names (Salo in Puhlar, Kandjia in woloff, Gbolou in Baoule, Gban in Bambara, etc.). In the region of Yamoussoukro, two varieties of okra are the most cultivated. There are Dioula variety and Baoule variety. Dioula variety gives ribbed fruits, more sticky than Baoule variety that gives non-ribbed fruit (Fig 1).
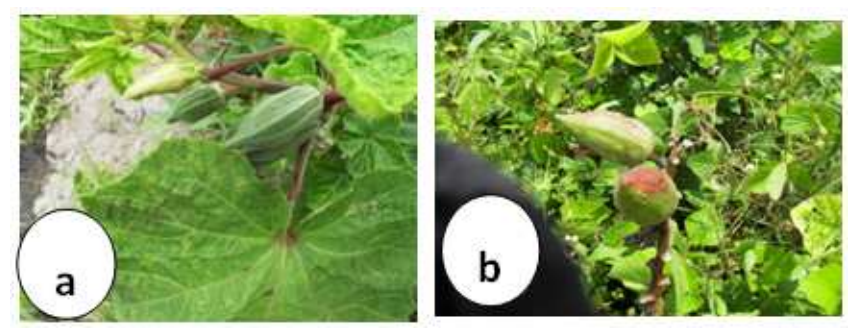

Figure1: Dioula Variety (a) and Baoule Variety (b)

Both varieties are rich in Iron, Calcium, Copper and Zinc. Indeed for Dioula variety, the levels are respectively: $14.98 \pm$ $12.97 \mathrm{mg} / 100$ dry matter, $564.85 \pm 274.60 \mathrm{mg} / 100$ dry matter, $0.66 \pm 0.27 \mathrm{mg} / 100$ dry matters, $3.65 \pm 0.77 \mathrm{mg} / 100$ dry matter. Those of the Baoule variety are respectively: $17.40 \pm 13.89 \mathrm{mg} / 100$ dry matter, $515.22 \pm 209.73 \mathrm{mg} / 100$ dry matter, $0.76 \pm 0.20 \mathrm{mg} / 100$ dry matter, $3.64 \pm 0.89$ $\mathrm{mg} / 100$ dry matter [9]. They also contain significant levels of magnesium, potassium, sodium and manganese. For Dioula 
variety, they are respectively: $484.01 \pm 46.10 \mathrm{mg} / 100$ dry matter, $591.30 \pm 454.78 \mathrm{mg} / 100$ dry matter, $29.91 \pm 14.07$ $\mathrm{mg} / 100$ dry matter, $4.55 \pm 4.35 \mathrm{mg} / 100$ dry matter. Those of the Baoule variety are respectively: $606.82 \pm 716.21 \mathrm{mg} / 100$ dry matter, $710.85 \pm 679.95 \mathrm{mg} / 100$ dry matter, $24.11 \pm$ $14.65 \mathrm{mg} / 100$ dry matter, $4.67 \pm 3.50 \mathrm{mg} / 100$ dry matter [10] All over Ivory Coast, it represents $24 \%$ of the vegetables consumed fresh and $41 \%$ of vegetables consumed dried [11]. Indeed, to preserve the large-scale production [12], the producer and / or consumer conducts its drying sliced then left untouched or powdered. The objective of this study is to determine the physicochemical properties of two varieties of okra traditionally dried.

\section{Materials and Methods}

\subsection{Plant Materials}

These varieties of okra were grown from December 2008 to April 2010 on eighteen (18) different sites in Yamoussoukro distributed as following: Six (6) in the village of Zatta, Six (6) in the village of Abouakouassikro Six (6) in the village of Sinzibo. Arrived at their respective maturity period that is to say, 45 days to the Dioula and 120 days for the Baoule variety variety, fresh fruit of each variety were harvested at random from each site. After harvest, the fruits of the same variety from the same village are put together.

These fruits are then cut into slices and then exposed to direct sunlight to dry for three weeks (Fig 2).

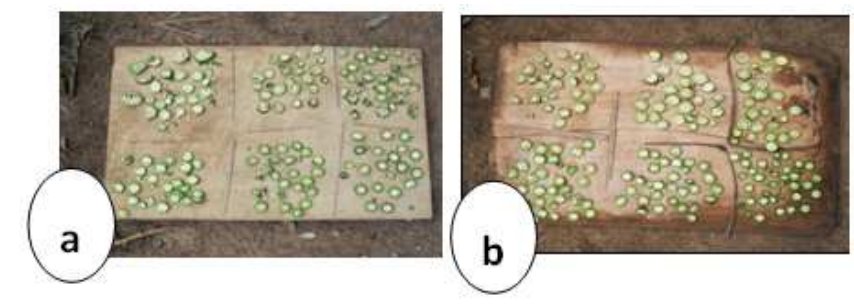

Figure 2: Dioula (a) and Baoule (b) varieties cut into slices and exposed to the sun.

After drying, those fruits are then pulverized with a mortar (Fig 3).
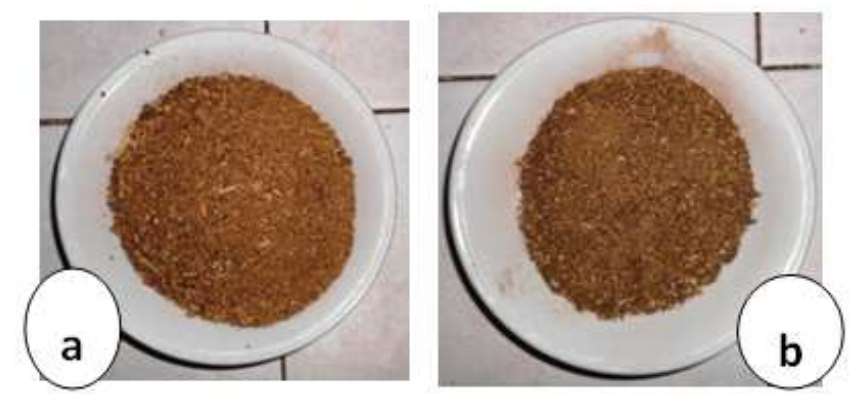

Figure 3 : Dioula (a) and Baoule (b) varieties powdered

\subsection{Chemical Analysis}

A phytochemical screening has highlighted the presence (or not) of different families of secondary metabolites: alkaloids, polyphenols, tannins, flavonoids, saponins, quinones, polyterpenes or sterols. This screening was performed on the aqueous extracts $(\mathrm{H} 2 \mathrm{O})$ varieties Baoule and Dioula sundried using the methodology described in Bagre (2007) [13]. Lipids were determined by Soxhlet extraction of a sample $10 \mathrm{~g}$, with hexane as solvent. Total proteins $(\mathrm{N} x$ 6.25) were determined by the method Kjeldalh. The water content was obtained after drying of $10 \mathrm{~g}$ of sample to $103^{\circ} \mathrm{C}$ in an oven until the constant weight. The extraction of vitamin $\mathrm{E}$ was performed according to the method described by Jedlicka et al. (2005). Reducing sugars were measured according to the method described by Bernfeld (1955). Total sugars were measured according to the method described by Dubois et al. (1956) [14]. The contents of total carbohydrate and starch are calculated according to the calculation method recommended by the FAO (1947) [15] which takes into account the contents of moisture, fat, protein and ash. The sucrose content is obtained by the difference between the total sugar and reducing sugars present in the sample [16]. The energy value was calculated from the total carbohydrate content, protein and fat using the conversion factors for energy ATWATER fruits namely $4 \mathrm{Kcal}$ per $1 \mathrm{~g}$ of carbohydrate, $9 \mathrm{kcal}$ per $1 \mathrm{~g}$ lipid and $4 \mathrm{kcal}$ per $1 \mathrm{~g}$ of protein [17]. Crude fiber was determined by the method of Weende (1977).

\subsection{Statistical Analysis}

The data were processed by analysis of variance test (ANOVA 1) using SPSS 18 software.

\section{Results and Discussion}

Table 1 shows the results of the phytochemical screening which helped to highlight the presence or absence of different families of secondary metabolites in samples of Baoule and Dioula varieties traditionally dried. These results show that these two varieties of dried okra are rich in leucoanthocyanes and catechin tannins. The presence of radical inhibitors plays an important role in the body. Indeed, these substances are able to neutralize free radicals preventing them from playing a role in the pathogenesis of hypertension, including the genesis of atherosclerosis. In addition, these substances are known for their properties and veinotonic vasculoprotective. These properties could be beneficial in the prevention of vascular damage that may occur in hypertensive patients [18]. Other families such as metabolic gallic tannins, sterols, terpenes, flavonoids, polyphenols, saponins and alkaloids are either very small, or trace or absent. Polyphenols, including tannins are recognized as powerful anti-nutrients of food. At a high dose, polyphenols inhibit the absorption of non-heme iron proteins. In particular, the tannins chelate iron formation of insoluble precipitates tannates iron in plant foods [19]. Saponins are harmless and irritating than $1 \%$ to $5 \%$ [20] to $1.5 \%$, their effects are reversible [21]. In addition, daily intake is the 
amount of $15 \mathrm{mg}$; saponins are not considered but have a cholesterol-lowering power [22] when they bind to cholesterol and bile salts, which has the advantage of reducing the intestinal absorption of cholesterol because they bind with bile acids and cholesterol. Therefore saponins have a considerable attractive interest, both harmful and beneficial.

Table 1: Results of phytochemical screening

\begin{tabular}{|c|c|c|c|c|c|c|}
\hline & \multicolumn{3}{|c|}{ Baoule variety } & \multicolumn{3}{|c|}{ Dioula Variety } \\
\hline & Zatta & Abouakouassikro & Sinzibo & Zatta & Abouakouassikro & Sinzibo \\
\hline Flavonoids & - & - & - & + & + & + \\
\hline Polyphenols & - & - & - & - & - & - \\
\hline Saponins & - & - & - & - & - & - \\
\hline Catechic tanins & +++ & +++ & +++ & +++ & +++ & +++ \\
\hline gallic tanins & ++ & ++ & ++ & ++ & ++ & ++ \\
\hline $\begin{array}{l}\text { Leucoanthocyane } \\
\text { s }\end{array}$ & +++ & +++ & +++ & +++ & +++ & +++ \\
\hline Alkaloids & - & - & - & - & - & - \\
\hline $\begin{array}{l}\text { Sterols et } \\
\text { terpenes }\end{array}$ & ++ & ++ & ++ & ++ & ++ & ++ \\
\hline
\end{tabular}

$(+++)$ : Strong presence, $(++)$ : Low attendance, $(+)$ : Traces, $(-)$ : No

Tables 2 and 3 show the results of physicochemical properties of the two varieties of okra dried.

The water content ranging from 6.90 to $7.85 \%$ for the two varieties of dried okra, with average grades of $7.28 \% \pm 0.50$ and $7.33 \pm 0.20 \%$ for respectively the Baoule variety and Dioula variety. The low water content of each of these dehydrated samples is a factor limiting the growth of microorganisms, agents of deterioration of food components [23]. This facilitates their preservation. These low water contents reflect the high solids content of the samples. These rates range from 92.14 to $93.10 \%$ for the varieties with respective averages of $92.71 \pm 0.50 \%$ for the Baoule variety and $92.60 \pm 0.30 \%$ for the Dioula variety. Indeed, the dry matter content of a sample corresponds to its mass after complete evaporation of free water.

Protein levels of these dehydrated samples range from 15.73 to $17.16 \%$. The Baoule variety has an average grade of $17.15 \pm 0.01 \%$ against $15.75 \pm 0.02 \%$ for the Dioula variety. According to the research results, the protein requirements are 14 to $25 \%$ of the diet dry matter depending on the species and physiological state. Thus, a diet containing these two varieties of okra would be beneficial to health knowing the important role played by proteins in the body. Indeed, proteins involved in growth, body development, maintenance, healing and replacement of worn or damaged tissue. They are also involved in the production of metabolic and digestive enzymes, the formation of hormones such as thyroxin and insulin. They cannot therefore be replaced by other nutrients like carbohydrates and lipids [24]. Foods containing less than $3 \%$ protein does not satisfy the protein needs of human being even if they are ingested in quantities that exceed the caloric needs.

The lipid content varies from 1.73 to $2.30 \%$. The Dioula variety has an average grade of $2.17 \pm 2.02 \pm 0.11 \%$ against $0.25 \%$ for the Baoule variety. These results indicate that these two varieties are not a good source of fat, saw the need to satisfy fat encrypted $4 \mathrm{~g} / \mathrm{kg} /$ jour $1 \mathrm{~g} / \mathrm{kg} / \mathrm{jour}$ in children and adults [25].

The ash content of a food is indicative of its overall mineral content. The percentages vary from 9.20 Ash $9.80 \%$ with average grades of $9.50 \pm 0.10 \%$ for the Dioula variety and $9.61 \pm 0.36 \%$ for the Baoule variety. These levels indicate that these samples are very rich in minerals. Indeed, J.B Kouassi and al $[9,10]$ reported that fruits of these samples are very rich in iron, calcium, copper, zinc , magnesium, potassium, sodium and manganese.

Levels of vitamin E ranged from 0.087 to $0.150 \%$ with an average grade of 0.087 to $0.150 \%$ and Baoule variety to Dioula variety.

Total carbohydrates range from 63.06 to $65.53 \%$ with an average grade of $63.92 \pm 0.75 \%$ for the Baoule variety against $65.24 \pm 0.25$ for the Dioula variety. These total carbohydrates are portioned out as follows:

- Total sugars with an average grade of $14.66 \pm 4.13 \%$ for the Baoule variety against $20 \%$ for the Dioula variety.

- Reducing sugars with an average grade of $0.86 \pm 0.05 \%$ for the Baoule variety against $0.83 \pm 0.05 \%$ for the Dioula variety.

- Starch with an average grade of $44.33 \pm 3.88 \%$ for the Baoule variety against $40.71 \pm 0.23 \%$ for the Dioula variety.

- Sucrose with an average grade of $13.10 \pm 4.35$ for the Baoule variety against $18.20 \pm 0.05$ for the Dioula variety. 
According to Souci and al (1994) [26], okra is rich in glucose, fructose, sucrose and cellulose.

Thus, carbohydrate needs, estimated $10 \mathrm{~g} / \mathrm{kg} /$ day for infants and 6-7 g/ kg / day in adults [25] can be met from these two varieties of okra.

Both varieties have average energy values of $342.51 \pm$ $2.94 \mathrm{kcal}$ for Baoule variety and $343.14 \pm 0.97$ for the Dioula variety. These results show that these two varieties of okra, mainly carbohydrate, represent a significant source of energy for human consumption.Crude fiber range from
7.58 to $11.33 \%$ with an average grade of $7.83 \pm 0.21 \%$ for the Baoule variety against $09.07 \pm 1.96$ for the Dioula variety. No significant difference was observed at the threshold of 5\% for the levels of lipids, total sugars, reducing sugars, water, ash, dry matter, starch, sucrose, crude fiber and energy values of two varieties of traditionally dried okra. However, a significant difference was observed in the 5\% threshold at the level of protein, vitamin $\mathrm{E}$ and total carbohydrate content.

Table 2: Physico-chemical properties of the Baoule variety. $(N=3)$

\begin{tabular}{|c|c|c|c|c|c|}
\hline & Zatta & Abouakouassikro & Sinzibo & AVERAGE & DEVIATION \\
\hline PROTEINS \% & 17.15 & 17.14 & 17.16 & 17.15 & 0.01 \\
\hline LIPIDS \% & 2.14 & 1.73 & 2.20 & 2.02 & 0.25 \\
\hline TOTAL SUGARS \% & 12 & 12 & 20 & 14.66 & 4.13 \\
\hline REDUCING SUGAR \% & 0.80 & 0.90 & 0.90 & 0.86 & 0.05 \\
\hline VITAMINS E \% & 0.087 & 0.087 & 0.087 & 0.087 & 0 \\
\hline MOISTURE \% & 7.85 & 6.90 & 7.10 & 7.28 & 0.50 \\
\hline ASH \% & 9.80 & 9.85 & 9.20 & 9.61 & 0.36 \\
\hline DRY MATTER \% & 92.14 & 93.10 & 92.90 & 92.71 & 0.50 \\
\hline TOTAL CARBOHYDRATES \% & 63.06 & 64.38 & 64.34 & 63.92 & 0.75 \\
\hline STARCH \% & 45.95 & 47.14 & 39.90 & 44.33 & 3.88 \\
\hline SUCROSE \% & 10.64 & 10.54 & 18.14 & 13.10 & 4.35 \\
\hline CRUDE FIBER \% & 7.58 & 7.96 & 7.96 & 7.83 & 0.21 \\
\hline ENERGY VALUE in kcal & 340.10 & 341.65 & 345.80 & 342.51 & 2.94 \\
\hline
\end{tabular}

Table 3: Physico-chemical properties of the Dioula variety. $(N=3)$

\begin{tabular}{|c|c|c|c|c|c|}
\hline & Zatta & Abouakouassikro & Sinzibo & AVERAGE & DEVIATION \\
\hline PROTEINS \% & 15.75 & 15.77 & 15.73 & 15.75 & 0.02 \\
\hline LIPIDS \% & 2.12 & 2.10 & 2.30 & 2.17 & 0.11 \\
\hline TOTAL SUGARS \% & 20 & 20 & 20 & 20 & 0 \\
\hline REDUCING SUGARS \% & 0.80 & 0.80 & 0.90 & 0.83 & 0.05 \\
\hline VITAMINS E \% & 0.15 & 0.15 & 0.15 & 0.15 & 0 \\
\hline MOISTURE \% & 7.50 & 7.10 & 7.40 & 7.33 & 0.20 \\
\hline ASH \% & 9.60 & 9.50 & 9.40 & 9.50 & 0.10 \\
\hline DRY MATTER \% & 92.3 & 92.90 & 92.60 & 92.60 & 0.30 \\
\hline TOTAL CARBOHYDRATES \% & 65.03 & 65.53 & 65.17 & 65.24 & 0.25 \\
\hline STARCH \% & 40.52 & 40.97 & 40.65 & 40.71 & 0.23 \\
\hline SUCROSE \% & 18.24 & 18.24 & 18.14 & 18.20 & 0.05 \\
\hline CRUDE FIBER\% & 11.33 & 7.76 & 8.14 & 9.07 & 1.96 \\
\hline ENERGY VALUE in kcal & 342.20 & 344.10 & 343.13 & 343.14 & 0.97 \\
\hline
\end{tabular}




\section{Conclusion}

Okra contains a variety of minerals $(\mathrm{K}, \mathrm{Ca}, \mathrm{Fe}, \mathrm{Mg}, \mathrm{Mn}$, $\mathrm{Cu}, \mathrm{Na}, \mathrm{Zn} . .$.$) , of vitamin \mathrm{E}$, sugars, proteins, and catechin tannins leucoanthocyanes ... which gives it an exceptional nutritional quality. The presence of these nutrients is a vegetable of choice for so-called vulnerable consumers: convalescents, children, pregnant and lactating women, the elderly. Souci and al reported that fresh fruit is rich in water $(88.60 \%)$. The high water is the main limiting factor for its preservation in the fresh state. Given its nutritional, steps should be taken to limit losses due to decay during periods of production in the areas of production to increase the availability of okra in time. The chain of cold preserves best the nutritional quality of the perishable products as the okra but this process is however very expensive. Drying at reasonable temperatures is a process with lower costs applicable to the okra.

\section{References}

[1] M. Camciuc, M. Deplagne, G. Vilarem, A. Gaset. Okra (Abelmoschus esculentus L. Moench.) Has crop with economic potential for set aside acreage in France, Industrial Crops and Products, Vol. 7, 1998, p.257 -264.

[2] S. Avallonea, T.W. E. Tiemtorea, C. Rivierb, S. Trècheb. Nutritional value of six multi- ingredient sauces from Burkina Faso, Journal of Food Composition and Analysis, Vol.21 p.553 -558, 2008.

[3] N. Sengkhamparn, L.M.C. Sagis, A. Renko de Vries, H. A. Henk Schols, T. Sajjaanantakul, G. J. Alphons, A.G.J. Voragen. Physicochemical properties of pectins from okra (Abelmoschus esculentus. L. Moench), Food Hydrocolloids, Vol. 24, 2008, p.35 -41.

[4] G.J.H. Grubben. Tropical vegetables and their genetic resource. IBPGR, FAO, Rome, 1977.

[5] S. Hamon, A. Charrier. Large variation of okra collected in Benin and Togo. Plant Genetic Resources Newsletter (FAO / 1BPGR) 56, 52-58, 1983.

[6] S. Hamon, A. Yapo. Disturbance induced within the genus Abelmoschus by the discovery of a second edible okra species in West Africa. Acta Hort. 182: 133-143, 1985.

[7] S. Hamon. Organization of its kind Abelmoschus (okra): Co-evolution of two species grown okra in West Africa (A.esculentus and A.caillei). Thesis Doctorate of Science. University of Paris -Sud, 1987, 216p

[8] S. Hamon, N. Chomchalow, C. Chantaraprasong, S. Chom chalow. Collecting germplasm Abelmoschus in Thailand. IBPGR / SEAN Newsletter (Bangkok), 11 (2): 2-6, 1987.

[9] J.B. Kouassi, M. Cisse-Camara, D. E. Sess, G. G. Tiahou, A. M. Ake , F. Y. Djohan. Determination of levels of iron, calcium, copper and zinc in two varieties of okra. Bulletin of the Royal Society of Sciences of Liege, Vol. 82 P. 22-32, 2013a.
[10] J.B. Kouassi, M. Cisse-Camara, D. E. Sess, G. G. Tiahou, F. Y. Djohan. Determination of levels of Magnesium, Potassium, Manganese and Sodium two varieties of okra. Journal of Applied Biosciences, Vol. 67 P. 5210-5218, 2013b.

[11] J.S. Siemonsma. Culture of okra Legume, a tropical fruit with special reference to the Ivory Coast (Abelmoschus spp.). Thesis, University of Wageningen (Netherlands), 1982.

[12] FAOSTAT (Food and Agricultural Organization of the United Nations). On-line and multilingual database currently covering international statistics, 2008. http://faostat.fao.org/foastat/

[13] I. Bagre, C. Bahi, G. Gnahoue, A.J Djaman, G.F Guede. phytochemical composition and in vitro assessment of the antifungal activity of extracts from the leaves of Morinda morindoides ( baker ) milne - redhead ( rubiaceae ) of Aspergillus fumigatus and Candida albicans. J. Sci. Pharm. Biol 8 (1):15-23, 2007.

[14] M. Dubois, K. Gilles, J. Hamilton, P. Rebers SMITN. Colorimetry method for determinations of sugars and related substances , Anal. Chem, 280, 350-356, 1956.

[15] FAO. Food and Agricultural Organization. Compositions foods calorie nutrients, FAO, Washington, 1947.

[16] S. Acourene, M. Tama. Physico-chemical characterization of the main cultivars of the region dates Ziban. Journal of Agricultural Research, p.59 -66, 1997.

[17] G. Linden. Technical analysis and control in the food industries. T2 Principles of analysis, Technical Documentation and techniques, 1981, pp. 414-416.

[18] S. Rokia, A.H Karadji, O. Dembele, D. Diallo. Diuretic and saluretic of a substance used in traditional medicine for the treatment of hypertension, Mali Medical, Volume XXIV, No. 4, 2009, p4 .

[19] S. Hercberg. Iron, vitamins, trace elements. I. Iron. As in teaching nutrition, Volume 1, 1994, p. 121-131

[20] D.E. Fenwick, D. Oakenfull. Saponin glad of some food plants and Prepared Foods. J. Sci Food Agric, 34, 186-191, 1983.

[21] G. Francis, Z. Kareem, HP.S. Makkar, K. Becker. The biological Action of saponins in animal systems: a review. British Journal of Nutrition, 88, 587-605, 2002.

[22] N. Guggenbühl. Dietician Nutritionist, News, 2003.

[23] J.C Cheftel, H. Cheftel. Introduction to Biochemistry and Food Technology. Technical documentation, Lavoisier, Vol 1, 1977, P383.

[24] O. Müller, M. Krawinkel. Malnutrition and health in developing countries. Canadian Medica Association Journal, 173 (3), P279 -286, 2005.

[25] L. Malassis, G. Ghersi. Nutritional food situation assessment. In Introduction to the food economy. Ed UREF Hatier, 1992, p. 33-38.

[26] W.S Souci, W. Fachman, H. Kraut. Food composition and nutrition tables, 5th edition, revised and supplemented, 1994, p 915 . 